\title{
Pengaruh pemberian plasma kaya trombosit dan karbonat hidroksiapatit pada proses penutupan defek tulang kepala hewan coba tikus
}

\author{
${ }^{1}$ Lucia Nirmalasari \\ ${ }^{1}$ Maximillian Ch. Oley \\ ${ }^{1}$ Eko Prasetyo \\ ${ }^{1}$ Mendy Hatibie \\ ${ }^{2}$ Lily L. Loho
}

\author{
${ }^{1}$ Bagian Bedah RSUP Prof. Dr. R. D. Kandou Manado \\ ${ }^{2}$ Bagian Patologi Anatomi Fakultas Kedokteran Universitas Sam Ratulangi, Manado \\ Email:wusiuchien@yahoo.com
}

\begin{abstract}
Recently, platelet rich plasma has been popular and its use has begin on human in developed countries. Platelet rich plasma is defined as autologus blood with concentration of platelets three to five times above baseline level, which contains at least seven growth factors like Platelet Derived Growth Factor (PDGF), Platelet Derived Angiogenesis Factor (PDAF), Platelet Derived Endothelial Growth Factor (PDEGF), Transforming Growth Factor Beta (TGF- $\beta$ ), Insulin like Growth Factor (IGF), Fibroblast Growth Factor (FGF), and Vascular Endothelial Growth Factor (VEGF). The golden standard for reconstruction of cranial bone defects demonstrates osteoconduction scaffold, osteoinduction like growth factors, and osteogenesis. Alloplastic biomaterials have revolutionalized craniofacial reconstruction. Carbonated hydroxyapatite (CHA) has been studied for years as implant material due to its similarity with the mineral component of bone. In this study we investigated and compare the effects of PRP and CHA on bone regeneration in rat cranial defects. This was an experimental study with a true experimental design on white male rats (Rattus norvegicus). Cranial deffects of $3 \mathrm{~mm}$ diameter were created in rat cranium and grafted with CHA and PRP combination, CHA alone, and control. The relationships among them were analyzed by using Mann Whitney and SPSS Statistics Program Package Version 22.0. The results showed that the experimental group of 2 weeks had no different between inflammatory reaction $(P=0.119)$, woven bone $(P=0.094)$ and lamellar bone $(P=0.130)$. At 4 weeks, a combination of PRP and CHA showed a superior growth of lamellar bone compared to CHA $(P=$ 0.009). Conclusion: A combination of PRP and CHA in bone regeneration showed a histological tendency toward increased bone formation. However, future investigations should be conducted in different period times.
\end{abstract}

Keywords: platelet rich plasma, carbonated hydroxyapatite, cranial defect

\begin{abstract}
Abstrak: Plasma kaya trombosit makin banyak digunakan dalam dunia kedokteran. Di negara maju pengunaannya sudah mulai diteliti pada manusia. Plasma kaya trombosit adalah fraksi plasma darah dengan konsentrasi platelet 3-5 kali diatas nilai normal yang mengandung sekurangkurangnya 7 faktor pertumbuhan, diantaranya Platelet Derived Growth Factor (PDGF), Platelet Derived Angiogenesis Factor (PDAF), Platelet Derived Endothelial Growth Factor (PDEGF), Transforming Growth Factor Beta (TGF- $\beta$ ), Insulin like Growth Factor (IGF), Fibroblast Growth Factor (FGF), dan Vascular Endothelial Growth Factor (VEGF) yang dapat meningkatkan proses osteogenesis. Karbonat hidroksiapatit adalah material pengganti tulang yang dapat mempercepat regenerasi jaringan tulang serta memiliki kandungan kalsium,fosfat dan karbonat yang mirip dengan tulang manusia. Tulang yang tumbuh pada awal berupa tulang muda yang memiliki serat kolagen yang tidak teratur dan banyak osteosit disebut tulang imatur. Tulang imatur kemudian akan diganti oleh tulang matur yang memiliki serabut kolagen yang teratur. Jenis penelitian ini ialah eksperimental pada 36 hewan coba tikus putih wistar (Rattus norvegicus). Defek kalvaria pada tikus dengan diameter $3 \mathrm{~mm}$ diisi sesuai perlakuan: plasma kaya trombosit dengan karbonat
\end{abstract}


hidroksiapatit, karbonat apatit tunggal, dan kontrol. Plasma kaya trombosit dibuat dari autologus darah tikus yang diberi perlakuan plasma kaya trombosit serta karbonat hidroksiapatit dan karbonat apatit tunggal. Data dianalisis dengan uji Mann Whitney dan diolah dengan SPSS. Hasil penelitian memperlihatkan pada minggu ke-2, tidak terdapat perbedaan bermakna reaksi inflamasi $(P=$ $0,119)$, tulang imatur $(P=0,094)$, dan tulang matur $(P=0,130)$ diantara ketiga perlakuan. Pada minggu ke-4, tulang matur yang terbentuk lebih banyak pada perlakuan plasma kaya trombosit dan karbonat hidroksiapatit $(P=0,009)$. Simpulan: Pemberian plasma kaya trombosit dan karbonat hidroksiapatit dapat meningkatkan proses penutupan defek tulang kepala hewan percobaan tikus.

Kata kunci : plasma kaya trombosit, karbonat hidroksiapatit, defek tulang kepala.

Dahulu dianggap trombosit hanya berfungsi sebagai faktor hemostasis, tetapi sekarang diketahui bahwa platelet mengandung beberapa faktor pertumbuhan yang penting untuk proliferasi, regenerasi dan diferensiasi jaringan sehingga merangsang peningkatan regenerasi tulang. ${ }^{1}$

Plasma kaya trombosit atau Platelet Rich Plasma (PRP) adalah autologous plasma yang memiliki konsentrasi platelet yang tinggi. Normal jumlah platelet dalam darah $150.000 / \mu 1$ sampai $350.000 / \mu \mathrm{l}$, ratarata 200.000/ $\mu$ l. Plasma kaya trombosit memiliki konsentrasi hingga $1.000 .000 / \mu{ }^{2}{ }^{2}$ dan merupakan produk autolog yang diproduksi dari whole blood melalui proses sentrifugasi sehingga menghasilkan konsentrasi tromosit yang tinggi dalam volume plasma yang rendah. Dengan banyaknya faktor pertumbuhan yang terkandung di dalamnya, plasma kaya trombosit berfungsi mempercepat regenerasi endotel, epitel dan epidermal, menstimuli angiogenesis, merangsang sintesa kolagen, mempercepat penyembuhan jaringan lunak, menurunkan jaringan parut pada kulit, mempercepat respon homeostasis pada cidera sehingga merangsang regenerasi tulang dan proses penyembuhan luka.,

Plasma kaya trombosit memiliki minimal tujuh faktor pertumbuhan, diantaranya Platelet Derived Growth Factor (PDGF), Platelet Derived Angiogenesis Factor (PDAF), Platelet Derived Endothelial Growth Factor (PDEGF), Transforming Growth Factor Beta (TGF- $\beta$ ), Insulin like Growth Factor (IGF), Fibroblast Growth Factor (FGF), dan Vascular Endothelial Growth Factor (VEGF). ${ }^{5}$ PDGF merupakan mediator paling banyak yang terdapat pada plasma kaya trombosit. PDGF akan melepaskan sel perisit dari lokasinya untuk mengaktifkan area angiogenik kemudian menyediakan sel mesenkim bebas lokal. Sel mesenkim yang bebas ini akan memicu PDGF untuk meningkatkan osteochondral progenitor yang kemudian berdiferensiasi menjadi osteoblas. $^{6} \quad$ TGF- $\beta$ merangsang sel mesenkim untuk mengadakan proliferasi dan rekrutmen osteogenik, meningkatkan produksi kolagen dan mineral matriks. ${ }^{7}$ IGF menstimulasi formasi tulang melalui proliferasi sel, serta diferensiasi dan sintesis kolagen. ${ }^{8}$ FGF meningkatkan proliferasi osteoblas sedangkan VEGF merangsang proses angiogenesis dan osifikasi. $^{9}$

Tulang merupakan komponen penting pada praktek klinis untuk mengisi defek tulang yang timbul akibat trauma, kongenital dan eksisi tumor. Banyak strategi diterapkan untuk menutup defek atau non-union tulang. Spicer et al. ${ }^{10}$ meneliti proses penutupan defek tersebut dengan menggunakkan beberapa material peng-ganti tulang. Komposisi utama jaringan tulang ialah $60 \%$ mineral, $30 \%$ matriks dan $10 \%$ air. ${ }^{11}$ Kombinasi ini memberikan fungsi mekanik yang dibutuhkan oleh tulang untuk penyangga tubuh dan pendukung gerakan. Komponen utama material anorganik ialah senyawa kalsium $24,5 \%$, fosfat $11,5 \%$, karbonat $5,8 \% .^{12}$

Suatu tandur tulang yang baik memiliki osteokonduksivitas, osteoinduksivitas, dan osteogenesis yang baik. $^{13}$ Osteokonduksi artinya mampu menjadi perantara sel untuk melakukan proliferasi untuk pertumbuhan jaringan tulang baru. Osteoinduksi yang baik mampu berikatan dengan protein yang diperlukan untuk 
pertumbuhan jaringan baru, sebagai contoh faktor pertumbuhan yang terdapat pada plasma kaya trombosit. Osteogenesis yaitu mendukung proses pertumbuhan tulang. ${ }^{14}$ Karbonat hidroksiapatit (CHA) dengan rumus kimia $\mathrm{Ca} 5(\mathrm{PO} 4, \mathrm{CO} 3) 3(\mathrm{OH})$ merupakan bahan pengganti tulang sintetik yang terbuat dari kalsium fosfat dan karbonat. ${ }^{15}$

\section{METODE PENELITIAN}

Jenis penelitian ini ialah eksperimental pada 36 ekor tikus putih wistar (Rattus Norvegicus) usia 22 minggu dengan berat 350-400 gram. Tikus dibagi secara acak menjadi tiga kelompok perlakuan. Tikus di anestesi dengan ketamin 20mg/kgbb intramuskular. Defek kalvaria pada tikus dibuat dengan diameter $3 \mathrm{~mm}$, insisi midline dari nasofrontal ke protuberensia occipital eksterna melewati sutura mid sagital. Defek kalvaria diisi sesuai perlakuan plasma kaya trombosit dengan karbonat hidroksiapatit, karbonat apatit tunggal dan kontrol. Plasma kaya trombosit dibuat dari autologus darah tikus sebanyak $2 \mathrm{~mL}$ dan di sentrifus $160 \mathrm{x}$ g selama 20 menit, kemudian sentrifus kedua $400 \times \mathrm{g}$ selama 15 menit. Bagian yang berwarna bening diambil, dilarutkan dengan kalsium chlorida. Tikus di euthanasia pada minggu ke dua dan ke empat dengan inhalasi overdosis eter.

\section{HASIL PENELITIAN}

Pada minggu ke-2 didapatkan reaksi inflamasi dan pembentukan tulang matur sebagai berikut (Tabel 1 dan Tabel 2).

Tabel 1. Data reaksi inflamasi

\begin{tabular}{ll}
\hline Perlakuan & Statistik \\
\hline Kontrol & Rerata 4 \\
& Nilai tertinggi 4 \\
CHA & Nilai terendah 4 \\
& Rerata 4 \\
& Nilai tertinggi 4 \\
CHA+PRP & Nilai terendah 4 \\
& Rerata 3 \\
& Nilai tertinggi 4 \\
& Nilai terendah 1
\end{tabular}

Tabel 2. Data tulang matur

\begin{tabular}{ll}
\hline Perlakuan & Statistik \\
\hline Kontrol & Rerata 5\% \\
& Nilai tertinggi 25\% \\
& Nilai terendah 0\% \\
& Rerata 16\% \\
CHA & Nilai tertinggi 40\% \\
& Nilai terendah 0\% \\
CHA+PRP & Rerata 2\% \\
& Nilai tertinggi 10\% \\
& Nilai terendah 0\% \\
\hline
\end{tabular}

Data pada reaksi inflamasi dihitung secara statistik dan didapatkan nilai $P=$ 0,119 artinya tidak terdapat perbedaan bermakna pada ketiga perlakuan. Data pada tulang imatur juga didapatkan nilai $P=$ 0,130 yang artinya secara statistik tidak didapatkan perbedaan bermakna pada ketiga perlakuan.

Gambar 1 memperlihatkan distribusi data minggu ke-2 pada tulang imatur. Walaupun didapatkan nilai $P=0,094$, namun terlihat kecenderungan untuk pembentukan tulang imatur lebih tinggi pada perlakuan plasma kaya trombosit dan karbonat hidroksiapatit.

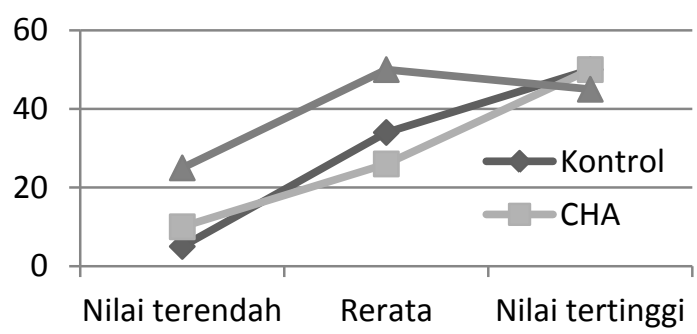

Gambar 1. Distribusi data minggu ke-2 pada tulang imatur

Gambar 2 memperlihatkan gambaran histopatologik sel radang, tulang imatur dan tulang matur pada minggu ke-2. Jumlah sel radang pada inflamasi lokal yang ditemukan lebih dari 50 sel.

Tabel 3 memperlihatkan data reaksi inflamasi pada minggu ke-4. Nilai $P=0,008$ menunjukkan bahwa perlakuan plasma kaya trombosit dan karbonat hidroksiapatit 
secara bermakna mengurangi reaksi inflamasi.
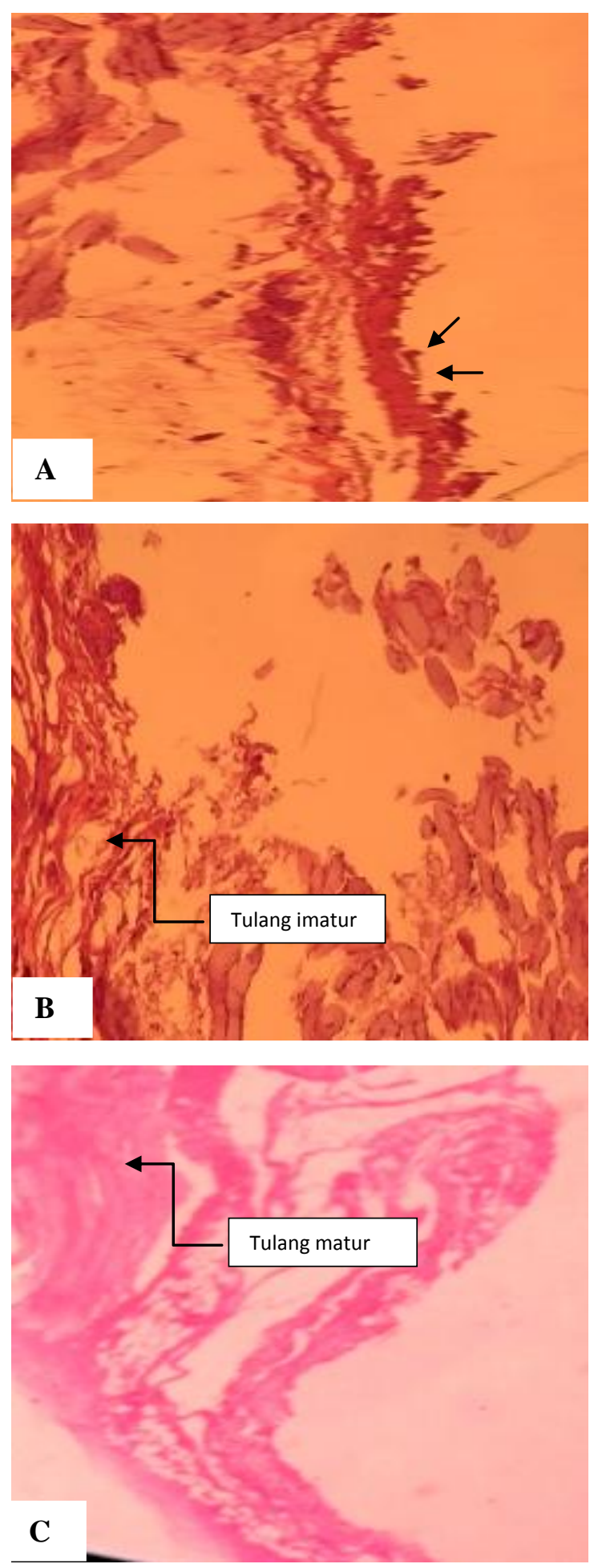

Gambar 2. A, Gambaran histopatologik pada perlakuan kontrol, anak panah menunjukkan sel radang; B, Perlakuan karbonat hidroksiapatit; C, Perlakuan plasma kaya trombosit+karbonat hidroksiapatit minggu ke 2.
Tabel 3. Reaksi inflamasi minggu ke-4

\begin{tabular}{lcc}
\hline & \multicolumn{2}{c}{ Perlakuan } \\
\hline & CHA & CHA+PRP \\
CHA & & $P=0,008$ \\
CHA+PRP & $P=0,008$ & \\
\hline
\end{tabular}

Data tulang imatur pada minggu ke-4 mendapatkan nilai $P=0,328$ yang menunjukkan tidak terdapat perbedaan bermakna diantara perlakuan. Pada Tabel 4 terlihat data statistik tulang matur dengan nilai $P=0,009$, berarti pada defek kalvaria yang diberi perlakuan plasma kaya trombosit dan karbonat hidroksiapatit terdapat pertumbuhan tulang matur lebih banyak dibandingkan perlakuan lain.

Tabel 4. Tulang matur minggu ke-4

\begin{tabular}{lcc}
\hline & \multicolumn{2}{c}{ Perlakuan } \\
\hline & CHA & CHA+PRP \\
CHA & & $P=0,009$ \\
CHA+PRP & $P=0,009$ & \\
\hline
\end{tabular}

Pada Gambar 3 dapat dilihat secara keseluruhan pembentukan jaringan tulang baru yaitu tulang imatur dan matur pada defek kalvaria yang diberi perlakuan. Gambar 4 menunjukkan gambaran histopatologik ketiga perlakuan. Pada perlakuan plasma kaya trombosit dan karbonat hidroksiapatit tampak kecenderungan pembentukan jaringan tulang baru lebih tinggi dibandingkan perlakuan yang lain.

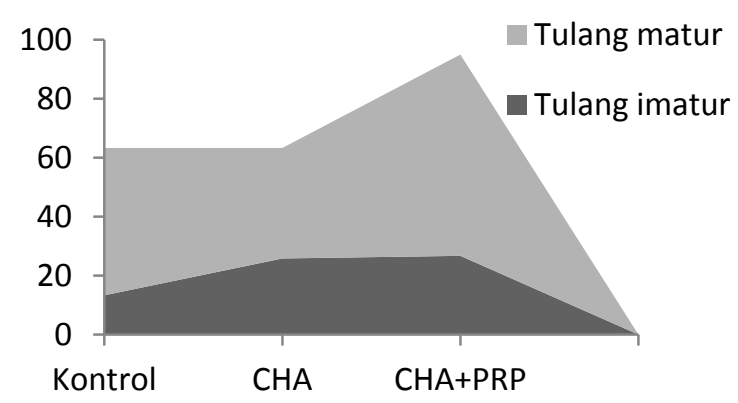

Gambar 3. Pertumbuhan jaringan tulang baru minggu ke-4 

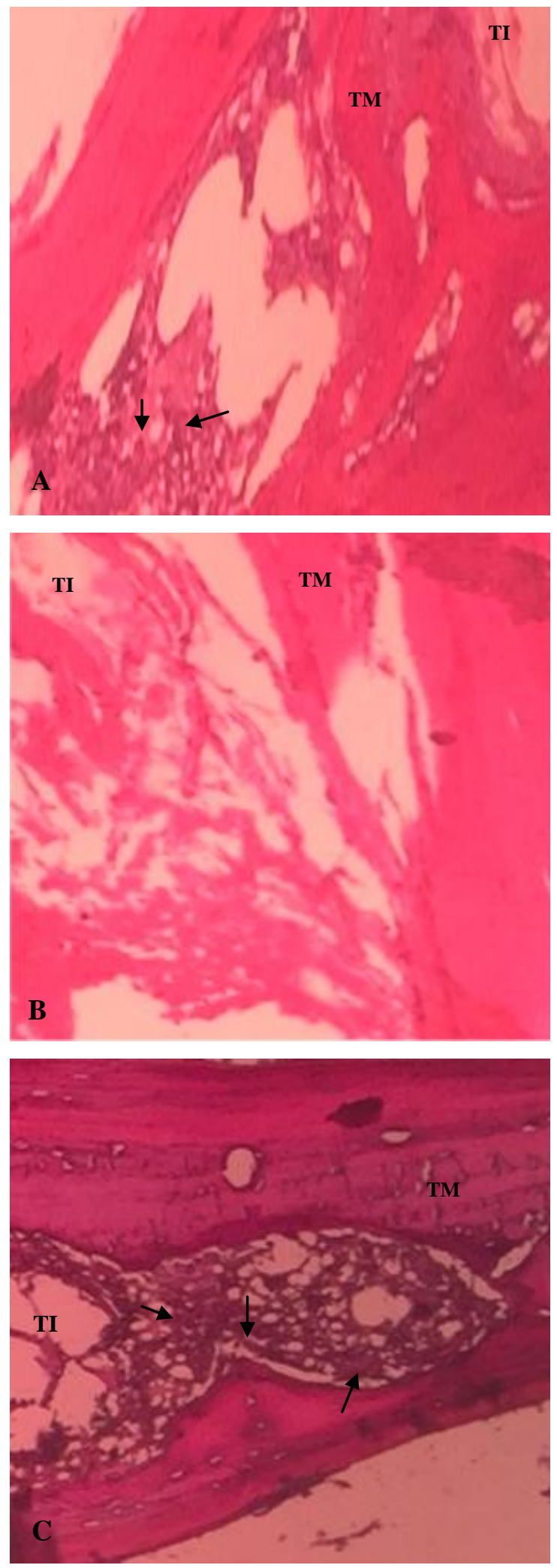

Gambar 4. Gambaran histopatologik pada perlakuan kontrol (A), karbonat hidroksiapatit (B), dan plasma kaya trombosit+karbonat hidroksiapatit (C) minggu ke 4. TI, tulang imatur; TM, tulang matur; anak panah menunjukkan sel radang

\section{BAHASAN}

Saat minggu ke-2, pada defek tulang mulai terbentuk jaringan ikat longgar yang sangat tipis. Setelah terjadinya fraktur, jaringan lunak yang meliputi beserta otot sekitarnya robek dan pembuluh darah yang melewati daerah fraktur ikut robek juga sehingga terjadi penumpukan hematom dalam medula. Darah dengan cepat akan membentuk bekuan darah, bercampur dengan tulang yang nekrosis akan mengaktivasi proses inflamasi, vasodilatasi, eksudasi plasma, sel-sel inflamasi akan bermigrasi ke tempat fraktur seperti sel PMN dan makrofag. Infiltrasi sel radang meningkat. ${ }^{16}$ Kim et al. ${ }^{17}$ menerangkan juga pada minggu ke-2 bahwa sel radang meningkat sehingga terbentuk jaringan ikat longgar dan formasi jaringan tulang baru yaitu tulang imatur yang lemah. Pada penelitian ini reaksi inflamasi minggu ke-2 ditemukan hampir sama pada setiap perlakuan, dengan nilai $P>0,05$, artinya dengan penambahan $\mathrm{CHA}$ atau $\mathrm{CHA}+\mathrm{PRP}$, proses peradangan tidak berkurang. Pada minggu ke 4 inflamasi fokal dengan 10-50 sel pada perlakuan $\mathrm{CHA}+\mathrm{PRP}$ paling kecil diantara semua perlakuan artinya dengan penambahan $\mathrm{CHA}+\mathrm{PRP}$ reaksi inflamasi berkurang untuk membentuk jaringan tulang baru.

Tulang imatur tampak sebagai anyaman serat kolagen yang tidak teratur, terdiri dari banyak osteosit dan memiliki kandungan garam mineral yang sedikit sehingga secara fisik jaringan tulang ini tidak kuat. Pada minggu ke-2 tulang imatur lebih awal terbentuk, yang mana kecenderungan lebih tinggi pada perlakuan CHA+PRP. Pada minggu ke-4, tulang imatur yang terbentuk pada perlakuan CHA dan CHA+PRP cenderung meningkat dua kali lipat dibanding perlakuan kontrol, namun secara statistik tidak ada perbedaan bermakna pada ketiga perlakuan. Hal ini mendukung penelitian yang dilakukan oleh Cooper et al. ${ }^{18}$ dan Yun et al. ${ }^{19}$ bahwa proses pembentukan jaringan baru akan bermakna setelah minggu ke-4 sehingga proses pembentukan lebih dini pada 2 
minggu memang tidak memberi peran besar.

Tulang matur pada pemeriksaan histopatologik merupakan susunan jaringan kolagen yang tersusun seperti lembaran lamelar dengan sel-sel osteosit didalamnya yang melingkar konsentris saluran ditengah disebut kanalis Haversi. Pada kanalis tersebut terdapat prosesus osteosit yang umumnya teratur dalam pola radial. ${ }^{20} \mathrm{Pada}$ minggu ke-2, rata-rata tulang matur belum terbentuk pada minggu pada perlakuan kontrol, CHA dan CHA+PRP. Pada minggu ke-4, pemberian karbonat apatit yang ditambah dengan plasma kaya trombosit cenderung terjadi peningkatan pertumbuhan tulang matur. Pemberian CHA+PRP lebih baik dari CHA dalam meningkatkan pertumbuhan tulang matur, sesuai dengan analisis statistik $P<0,05$.

Pada proses penutupan defek tulang kepala, tulang imatur dan tulang matur bersama-sama membentuk jaringan tulang baru. Perlakuan $\mathrm{CHA}+\mathrm{PRP}$ memiliki kecenderungan lebih tinggi pada pembentukan tulang imatur dan matur dari perlakuan CHA dan kontrol. Hal ini sesuai dengan acuan pustaka yang mengatakan bahwa dalam plasma kaya trombosit memiliki sedikitnya tujuh faktor pertumbuhan yang bersifat sebagai stimulator pembentukan jaringan tulang baru.

\section{SIMPULAN}

Proses penutupan defek kalvaria merupakan proses penulangan intramembranosa yaitu pembentukan dari jaringan mesenkim, tanpa kartilago, menjadi jaringan tulang. Plasma kaya trombosit dan karbonat hidroksiapatit secara bermakna menurunkan reaksi inflamasi dan meningkatkan pertumbuhan tulang matur pada minggu ke-4.

Penelitian lebih lanjut diperlukan dalam jumlah sampel yang lebih besar dan berbeda waktu penelitian untuk mengetahui pengaruh plasma kaya trombosit tunggal terhadap proses penutupan defek kalvaria.

\section{DAFTAR PUSTAKA}

1. Utomo RDN. Effect of making method of platelet rich plasma. Med Ortho. 2012;1(1):26-31.

2. RE M. Platelet rich plasma What is PRP and what is not PRP. J Implant Dent. 2001;10:225-8.

3. Rodroguez I, Kalaf EAG, Bowlin GL, Sell SA. Platelet rich plasma in bone regeneration engineering the delivery for improved clinical efficacy. J Biomed Res Int. 2014;1-15. Article ID 392398.

4. Lippross S, Alini M. Platelet rich plasma for bone healing to use or not to use. J Am Orthop. 2014;25-9.

5. Civinini RMA. The use of autologous blood derived growth factors in bone regeneration. J Clin Case Miner Bone Metab. 2011;8(1):25-31.

6. Caplan AI, Correa D. PDGF in bone formation and regeneration: New insights into a novel mechanism involving MSCs. J Orthop Res. 2011;29(12):1795-803.

7. Beck LS, Deguzman L, Lee WP, Xu Y, McFatridge LA, Gillet NA, et al. TGF $\beta 1$ induces bone closure of skull defects. J Bone Miner Res. 1991;6(11):1257-60.

8. Ruth DA, LI Gold VH. Immunolocalization of transforming growth factor $\beta 1, \beta 2$ and $\beta 3$ and insulin like growth factor in prematur cranial suture fusion. Plast Reconstr Surg. 1997;2(99):300-9.

9. Smith RG, Gassmann CJ CM. Platelet rich plasma properties and clinical applications. J Lancaster Gen Hosp. 2007;2(2):73-8.

10. Spicer PP, Kretlow JD, Young S, Jansen J a, Kurtis F, Mikos AG. Evaluation of bone regeneration using the rat critical size calvarial defect. Nat Protoc. 2012;7(10):1918-29.

11. Dorozhkin S. Medical application of orthophosphate bioceramics. Available from: http://cceasmag.org/ bio_2011/vol1/Dorozhkin-CaPO4bioceramics.pdf

12. Vigorita VJ. Orthopaedic Pathology (2nd ed). United States of America: Lippincott Williams \& Wilkins, 2008; p. 1-42.

13. Nandi S, Roy S, Mukherjee P, Kundu B, Basu D. Orthopaedic application of 
bone graft and bone substitutes. Indian J Med Res. 2010;7:15-30.

14. Miller MD. Review of Orthopaedics (4th ed). Philadelphia: Saunders, 2004; p. 1-21.

15. Mathur KK, Tatum SA, Kellman RM. Carbonated apatite and hydroxyapatite in craniofacial reconstruction. Arch Facial Plast Surg. 2003;5(5):379-83.

16. Choi JY, Choi SH. The effects of newly formed synthetic peptide on bone regeneration in rat calvarial defects. J Periodontal Implant Sci. 2010;40(1):11-8.

17. Kim BS, Park KE, Kim MH, You HK, Lee J, Won HP. Effect of nanofiber content on bone regeneration of Silk FibroinPoly (E Caprolactone) Nano/
Microfibrous Composite Scaffolds. Int J Nanomedicine. 2015;10:485-502.

18. Cooper GM, Mooney MP, Gosain AK, Campbell PG, Losee JE, Huard J. Testing the critical size in calvarial bone defects. Plast Reconstr Surg. 2010;123(6):1685-92.

19. Yun JH, Yoo JH, Choi SH, Lee MH, Lee SJ, Song SU, et al. Synergistic effect of bone marrow derived mesenchymal stem cells and platelet rich plasma on bone regeneration of calvarial defects in rabbits. Tissue Eng Regen Med. 2012;9(1):17-23.

20. HG Anatomy of Human Body. Philadelphia: Lea\&Febiger, 2000; p. 551-83. 